УДК 635.13:[631.527+631.53.026]

(C) 2013

Хареба В. В., доктор сільськогосподарських наук, член-кореспондент НААН

Національна академія аграрних наук України

Позняк О. В., молодший науковий співробітник,

Хареба О. В., кандидат сільськогосподарських наук

Дослідна станція «Маяк» Інституту овочівництва і баштанництва НААН

\title{
ЗБЕРІГАННЯ СЕЛЕКЦІЙНИХ ФОРМ МАТОЧНИХ КОРЕНЕПЛОДІВ МОРКВИ ПОСІВНӦ̈
}

\section{Рецензент - доктор сільськогосподарських наук Г. П. Жемела}

Розглянуто модифікований спосіб зберігання маточних коренеплодів селекційних форм моркви посівної, в основі якого - скорочення втрат коренеплодів під час зимового зберігання та отримання чистосортного насіння заданих комбінацій у процесі селекиійної роботи. Розглянутий модифікований спосіб зберігання маточних коренеплодів моркви посівної безпосередньо у полі перспективний для освоєння $в$ науково-дослідних установах та насінницьких господарствах у зонах Північного Лісостепу та Полісся Украӥни.

Ключові слова: овочівницттво, морква посівна, спосіб, зберігання.

Постановка проблеми. Відомі способи зберігання маточних коренеплодів моркви передбачають іï зберігання в сховищах зі штучним мікрокліматом, 3 активною або природною вентиляцією, в траншеях, а також у грунті. Зберігаючи маточні коренеплоди у сховищах і траншеях не завжди вдається дотримуватися режиму зберігання, що може викликати значні втрати коренеплодів (близько $40 \%$ ) від ураження хворобами та пошкодження шкідниками. У зв'язку з цим необхідно використовувати препарати (фунгіциди) для обробки посівів моркви на маточник i маточників перед закладанням на зберігання, проводити дезинфекцію сховищ.

Аналіз основних досліджень і публікацій, у яких започатковано розв'язання проблеми. За даними наукових досліджень, зберігання в сховищах невеликих партій селекційного матеріалу економічно невигідно $[1,7]$. В умовах півдня України можливе перезимовування маточників коренеплідних овочевих рослин, зокрема моркви, в полі, де їх необхідно підгортати землею $[2,3,6]$. За таких умов, коли не проводиться осіннє пересаджування маточників, неможливо провести оцінку коренеплодів за морфологобіометричними показниками, їх пошкодження шкідниками і хворобами тощо. Отже, таким способом можна вирощувати тільки репродукційне насіння моркви. Використання даного способу стосовно вирощування оригінального та елітного насіння, а також у селекційній роботі недопустиме без його модифікації.

Мета і завдання досліджень. Метою експериментів було оцінити модифікований спосіб зберігання маточних коренеплодів селекційних форм моркви посівної, в основі якого скорочення втрат коренеплодів під час зимового зберігання, а також отримання чистосортного насіння заданих комбінацій у процесі селекційної роботи.

Завдання досліджень полягало в обгрунтуванні особливостей ефективного способу зберігання маточних коренеплодів моркви для вирощування селекційного матеріалу на невеликих площах.

Методика проведення досліджень. Об'єкт досліджень - селекція і насінництво моркви посівної. Предмет досліджень - маточні коренеплоди. Пошукова робота проводилася на Дослідній станції «Маяк» ІОБ НААН, у перехідній зоні від Лісостепу до Полісся України. У роботі керувалися сучасними методичними рекомендаціями $[4,5,8]$.

Результати досліджень. Суть модифікованого способу полягає в тому, що маточні коренеплоди селекційного матеріалу моркви в умовах північного Лісостепу та Полісся України вирощуються за загальноприйнятими технологіями, сівба - в третій декаді квітня - першій декаді травня. Після викопування в першій декаді жовтня коренеплоди оцінюються й відбираються за морфологічними і біометричними ознаками та господарськи цінними показниками, - відповідно, вибраковуються нетипові, уражені хворобами і шкідниками, тріснуті, ті, що утворили квітконоси в перший рік. Коренеплоди групуються й висаджуються у відповідності до програми селекційного процесу (наприклад, стерильні материнські лінії та фертильні лінії-закріплювачі стерильності; стерильні материнські й фертильні батьківські лінії) на постійне місце на ізольованих ділянках без закладання на зберігання у сховище. В разі настання перших заморозків прово- 


\section{СІЛЬСЬКЕ ГОСПОДАРСТВО. РОСЛИННИЦТВО}

диться додаткове підгортання грунту шаром близько 10-15 см і укриття соломою шаром до 20 см, які знімаються після перезимівлі у першій декаді квітня.

Даний спосіб дає можливість зменшити втрати маточних коренеплодів від пошкодження шкідниками та ураження хворобами, що розвиваються у сховищі або траншеях; запобігти підмерзанню або передчасному проростанню маточних коренеплодів внаслідок порушення режиму зберігання (зниження або підвищення температури, недотримання вологості); забезпечити краще приживання маточних коренеплодів (близько 40 \% порівняно 3 маточниками, висадженими навесні), більш раннє їх відростання (на 30 діб). Відносно ранній початок цвітіння дає можливість уникнення вірогідного перезапилення 3 дикою морквою (часова ізоляція), а отже, уникнення небажаного засмічення гібридного та селекційного матеріалу; насіннєві рослини в разі висаджування маточних коренеплодів восени краще розвиваються порівняно 3 висадженими навесні, за рахунок більш ефективного використання весняної вологи в грунті. До того ж одержане насіння має високі господарські показники й посівні якості. Ранньовесняна сівба насіння у відкритий грунт забезпечує отримання повністю сформованих типових коренеплодів, що є необхідним у процесі всебічної оцінки коренеплодів перед висаджуванням у грунт, оскільки за літніх строків сівби отримані коренеплоди-штеклінги мають не в повній мірі виражені ознаки сортів i ліній. Ретельна оцінка і добір селекційного матеріалу у поєднанні з браковкою за габітусом на-

\section{БІБЛІОГРАФІЯ}

1. Бондаренко Г. Л. Зберігання маточників моркви // Г.Л.Бондаренко, Л.П.Бєлашова, I. М. Гордієнко / Овочівництво і баштанництво: Міжвід. темат. наук. зб. - Х. : ТОВ «Виробниче підприємство «Плеяда», 2008. - Вип. 54. С. 285-291.

2. Грушник Д. В. Сравнительная оценка различных способов семеноводства моркови в Крыму // Д. В. Грушник / Овочівництво і баштанництво: Міжвід. темат. наук. зб. - Х. : ТОВ «Виробниче підприємство «Плеяда», 2008. Вип. 54. - С. 131-136.

3. Костанчук Р. Г. Беспересадочное семеноводство моркови в Крыму // Р. Г. Костанчук, Д. В. Грушник / Овочівництво і баштанництво: Міжвід. темат. наук. зб. - Х. : ВАТ «Харківська друкарня № 2», 2005. - Вип. 50. - С. 430438. сіннєвого куща протягом вегетації дають змогу отримати чистосортне насіння відповідної комбінації. Висаджування сформованих груп (комбінацій) на ізольованих ділянках забезпечує отримання більшої кількості порівняно зі штучним запиленням високоякісного гібридного насіння без застосування ізоляторів, що суттєво знижує матеріальні й трудові витрати. Солома після розгортання може бути використана на місці в якості мульчі.

Не зважаючи на низку недоліків (необхідність додаткового укриття посадок соломою, у разі наявності снігового покриву - снігом, за прогнозування зниження температури повітря до $-20{ }^{\circ} \mathrm{C}$ i нижче в зимовий період; своєчасного розгортання шару грунту навесні на початку відростання коренеплодів, не допускаючи пошкодження точки росту, закладання отрутохімікатів для запобігання імовірного пошкодження коренеплодів моркви гризунами), розроблений спосіб виявився більш ефективним для вирощування селекційного матеріалу на невеликих площах у порівнянні з зимовим зберіганням маточників у сховищах різного типу i траншеях та вирощуванням моркви безпересадковим способом шляхом літнього посіву, який неможливо використовувати в селекційному процесі.

Висновок. Розглянутий модифікований спосіб зберігання маточних коренеплодів моркви посівної безпосередньо у полі перспективний для освоєння в науково-дослідних установах та насінницьких господарствах у зонах Північного Лісостепу та Полісся України.

4. Методика дослідної справи в овочівництві i баштанництві // [За ред. Г. Л. Бондаренка i К. І. Яковенка]. - Х. : Основа, 2001.-369 с.

5. Насінництво і насіннєзнавство овочевих i баштанних культур // [За ред. Т. К. Горової]. К.: Аграрна наука, 2003. - 328 с.

6. Недбал Р. Ф. Безвысадочный способ выращивания семян петрушки в Крыму // Р. Ф. Недбал / Овочівництво і баштанництво: Міжвід. темат. наук. зб. - Х. : «Магда, ЛТД», 2006. - Вип. 52. - C. 26-34

7. Пономарева Г. Н. Режимы и способы хранения маточников столовой моркови // Пономарева Г. Н. - М. : Глав. упр. по производству овощ. и бахчевых культур Министерства плодоовощного хозяйства СССР, 1983. - 8 с.

8. Сучасні методи селекції овочевих і баштанних культур // [За ред. Т. К. Горової i К. І. Яковенка]. - Харків : Основа, 2001. - 644 с. 